\section{Meliolaceae of Kerala, India - XXX new species and new records}

\author{
V.B. Hosagoudar ${ }^{1} \&$ M.C. Riju ${ }^{2}$ \\ 1,2 Tropical Botanic Garden and Research Institute, Palode, \\ Thiruvananthapuram, Kerala 695562, India \\ Email: ${ }^{1}$ vbhosagoudar@rediffmail.com
}

\section{Irenopsis trichiliae sp. nov.}

(Fig. 1)

\section{Material examined}

10.xi.2007, on leaves of Trichilia sp. (Meliaceae), $16^{\text {th }}$ mile, Padinharathara, Wayanad, Kerala, India, coll. M.C. Riju HCIO 48177 (holotype), TBGT 2913 (isotype), (Myco Bank \# 518227).

Coloniae epiphyllae, subdensae, dispersae, ad $2 \mathrm{~mm}$ diam., confluentes. Hyphae rectae vel flexuosae, opposite vel alternatim, acuteque vel laxe ramosae, laxe vel arte reticulatae, cellulae 11-33 x 6-11 $\mu \mathrm{m}$. Appressoria alternata, antrorsa vel subantrorsa, 13-26 $\mu \mathrm{m}$ longa; cellulae basilares cylindraceae vel cuneatae, 4-11 $\mu \mathrm{m}$ longae; cellulae apicales globosae, angularis, sublobatae vel fortiter lobatae, 8-18 $\mathrm{x}$ 11-18 $\mu \mathrm{m}$. Phialides appressoriis intermixtae, oppositae vel unilateralis, ampulliformes, 17-24 x 6-9 $\mu \mathrm{m}$. Perithecia dispersa, ad 209 $\mu \mathrm{m}$ diam.; setae peritheciales 0-5 numero, rectae, simplices, ad apicem obtusae, ad $198 \mu \mathrm{m}$ longae; ascosporae cylindraceae, 4-septatae, leniter constrictus ad septatae, $37-46 \times 15-18 \mu \mathrm{m}$.

Date of publication (online): 26 April 2010

Date of publication (print): 26 April 2010

ISSN 0974-7907 (online) | 0974-7893 (print)

Editor: Richard Mibey

Manuscript details:

Ms \# 02058

Received 13 September 2008

Final revised received 24 April 2009

Finally accepted 23 February 2010

Citation: Hosagoudar, V.B. \& M.C. Riju (2010). Meliolaceae of Kerala, India - XXX new species and new records. Journal of Threatened Taxa 2(4): 824-826

Copyright: (C) V.B. Hosagoudar \& M.C. Riju 2010. Creative Commons Attribution 3.0 Unported License. JoTT allows unrestricted use of this article in any medium for non-profit purposes, reproduction and distribution by providing adequate credit to the authors and the source of publication.

Acknowledgements: We thank the Director, Tropical Botanic Garden and Research Institute, Palode, Thiruvananthapuram, Kerala for the facilities. We are grateful to the Ministry of Environment and Forest, New Delhi for financial support and to the Forest Department, Govt. of Kerala for forest permission

\section{OPEN ACCESS | FREE DOWNLOAD}

Colonies epiphyllous, subdense, scattered, up to $2 \mu \mathrm{m}$ in diam., confluent. Hyphae straight to flexuous, branching opposite to alternate at acute to wide angles, loosely to closely reticulate, cells $11-33 \times 6-11 \mu \mathrm{m}$. Appressoria alternate, unilateral, antrorse to subantrorse, 13-26 $\mu \mathrm{m}$ long; stalk cells cylindrical to cuneate, $4-11 \mu \mathrm{m}$ long; head cells globose, angular, sublobate to deeply lobate 8-18 x 11-18 $\mu \mathrm{m}$. Phialides mixed with appressoria, opposite to unilateral, ampulliform, 17-24 x 6-9 $\mu \mathrm{m}$. Perithecia scattered, up to $209 \mu \mathrm{m}$ in diameter; perithecial setae 0-5 in number, straight, simple, obtuse at the apex, up to $198 \mu \mathrm{m}$ long; ascospores cylindrical, 4-septate, slightly constricted at the septa, 37-47 x 15-18 $\mu \mathrm{m}$.

Irenopsis chukrasiae Hosag., I. inidica (Anahosur) Hosag., I. murrayae Hosag. \& Rajkumar are known on the members of the family Meliaceae (Hosagoudar 1996; Hosagoudar et al. 2001). Irenopsis trichiliae differs from I. chukrasiae in having only unicellular stalk cells of the appressoria and from I. indica in having straight hyphae and $0-5$ perithecial setae. It also differs from I. murrayae in having angular to lobate head cells of the appressoria.

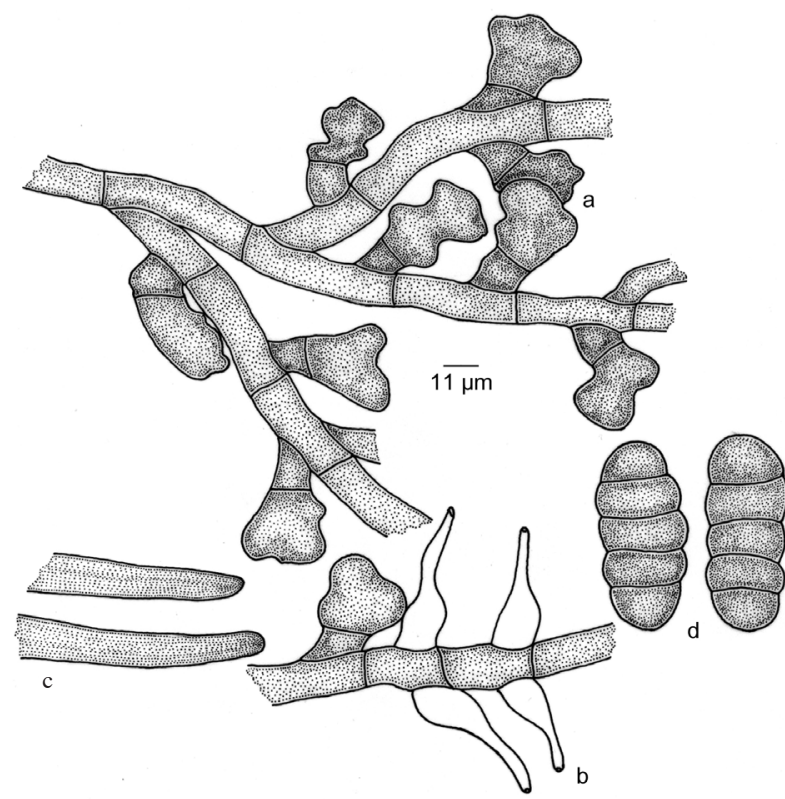

Figure 1. Irenopsis trichiliae sp. nov. a - Appressorium; b - Phialide; c - Apical portion of the perithecial setae; $d$ - Ascospores 


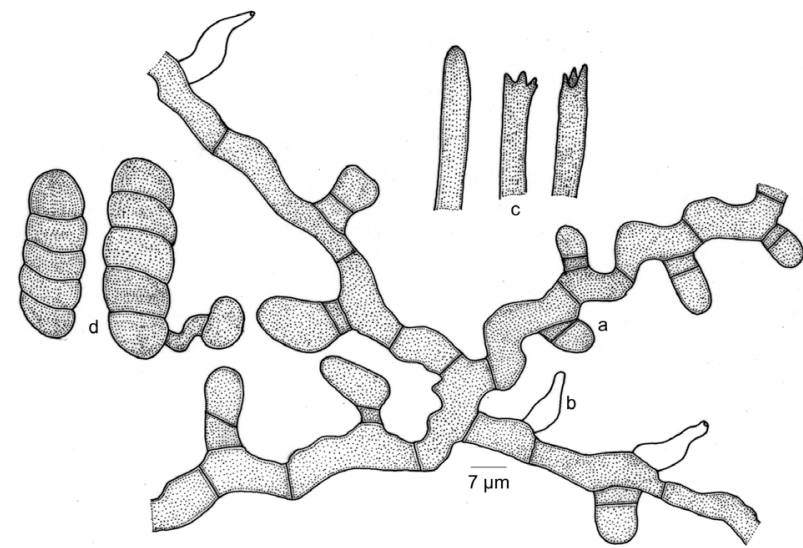

Figure 2. Meliola ailanthicola sp. nov.

a - Appressorium; b - Phialide; c - Apical portion of the mycelial setae; d-Ascospores

\section{Meliola ailanthicola sp. nov.}

(Fig. 2)

\section{Material examined}

30.ix.2007, on leaves of Ailanthus triphysa malabarica (Dennst.) Alston (Simaroubaceae), $16^{\text {th }}$ mile, Padinharathara, Wayanad, Kerala, India, coll. M.C. Riju HCIO 48170 (holotype), TBGT 2906 (isotype), (MycoBank \# 518228).

Coloniae hypophyllae, tenues, ad $4 \mathrm{~mm}$ diam., confluentes. Hyphae anfractuae, alternate vel opposite, acuteque vel laxe ramosae, laxe vel arte reticulatae, cellulae 13-33 x 4-9 $\mu \mathrm{m}$. Appressoria alternata vel unilateralis, recta vel curvula, antrorsa, subantrorsa vel retrorsa, 13-27 $\mu \mathrm{m}$ longa; cellulae basilares cylindraceae vel cuneatae, 4-16 $\mu \mathrm{m}$ longae; cellulae apicales ovatae, globosae, truncatae vel leniter lobatae, 8-13 x 6-9 $\mu \mathrm{m}$. Phialides appressoriis intermixtae, oppositae, alternatae vel unilateralis, ampulliformes, 13-22 x 4-9 $\mu \mathrm{m}$. Setae myceliales dispersae, simplices, rectae, ad apicem acutae, obtusae vel 2-5 dentatae, ad $400 \mu \mathrm{m}$ longae. Perithecia dispersa, ad $160 \mu \mathrm{m}$ diam.; ascosporae obovoideae, 4-septatae, leniter constrictus ad septatae, 37-44 x 13-16 $\mu \mathrm{m}$.

Colonies hypophyllous, thin, up to $4 \mathrm{~mm}$ in diam., confluent. Hyphae crooked, branching alternate to opposite at acute to wide angles, loosely to closely reticulate, cells $13-33 \times 4-9 \mu \mathrm{m}$. Appressoria alternate to unilateral, straight to curved, antrorse, subantrorse to retrorse, 13-27 $\mu \mathrm{m}$ long; stalk cells cylindrical to cuneate, 4-16 $\mu \mathrm{m}$ long; head cells ovate, globose, truncate to slightly lobate, $8-13 \times 6-9 \mu \mathrm{m}$. Phialides mixed with appressoria, opposite, alternate to unilateral, ampulliform, 13-22 x 4-9 $\mu \mathrm{m}$. Mycelial setae scattered, simple, straight, acute, obtuse to 2-5 dentate at the tip, up to $400 \mu \mathrm{m}$ long. Perithecia scattered, up to $160 \mu \mathrm{m}$ in diam.; ascospores obovoidal, 4- septate, slightly constricted at the septa, 37$44 \times 13-16 \mu \mathrm{m}$.

This species differs from Meliola ailanthi Sharma et al. emend. Hosag. in having strongly appressed colonies on the lower surface of the leaves and having distinctly crooked mycelium (Hosagoudar 1996).

\section{Meliola kamettiae sp. nov.}

(Fig. 3)

\section{Material examined}

29.ix.2007, on leaves of Kamettia caryophyllata Roxb. (Apocynaceae), 16 $6^{\text {th }}$ mile, Padinharathara, Wayanad, Kerala, India, coll. M.C. Riju HCIO 48175 (holotype), TBGT 2911 (isotype), (MycoBank \# 518229).

Coloniae hypophyllae, dispersae, densae, velutinae, ad $4 \mathrm{~mm}$ diam., raro confluentes. Hyphae rectae vel subrectae, plerumque opposite acuteque vel laxe ramosae, laxe vel arte reticulatae, cellulae 13-35 x 4-7 $\mu \mathrm{m}$. Appressoria alternata vel unilateralis, recta, antrorsa, 11-20 $\mu \mathrm{m}$ longa; cellulae basilares cylindraceae vel cuneatae, 2-9 $\mu \mathrm{m}$ longae; cellulae apicales ovatae, globosae, 7-13 x 6-11 $\mu \mathrm{m}$. Phialides appressoriis intermixtae, oppositae, alternatae, unilateralis, ampulliformes, 11-22 x 4-7 $\mu \mathrm{m}$. Setae myceliales numerosae, ad $260 \mu \mathrm{m}$ longae, simplices, rectae, paucae curvulae vel uncinatae, ad apicem obtusae, bifidae, trifidae, saepe subdentatae, furcatae vel ramosae, ramulae ad $30 \mu \mathrm{m}$ longae. Perithecia dispersa, ad 150 $\mu \mathrm{m}$ diam.; ascosporae cylindraceae, 4-septatae, leniter constrictus ad septatae, 26-33 x 8-11 $\mu \mathrm{m}$.

Colonies hypophyllous, scattered, dense, velvety, up to $4 \mathrm{~mm}$ in diam., rarely confluent. Hyphae straight to substraight, branching mostly opposite at acute to wide angles, loosely to closely reticulate, cells $13-35 \times 4-7 \mu \mathrm{m}$. Appressoria alternate, unilateral, straight, antrorse, 11-20 $\mu \mathrm{m}$ long; stalk cells cylindrical to cuneate, 2-9 $\mu \mathrm{m}$ long; head cells ovate, globose, 7-13 x 6-11 $\mu \mathrm{m}$. Phialides mixed with appressoria, opposite, alternate, unilateral, ampulliform, 11-22 x 4-7 $\mu \mathrm{m}$. Mycelial setae numerous, up to $260 \mu \mathrm{m}$ long, simple, straight, few slightly curved

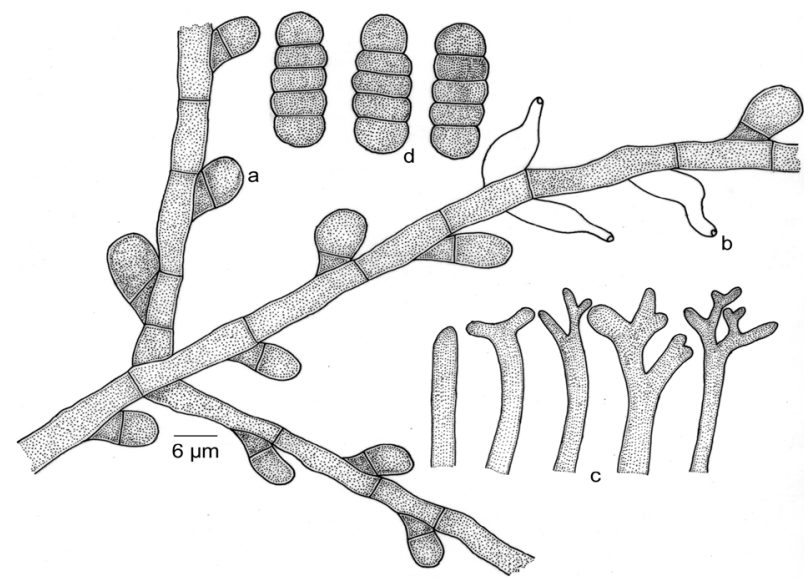

Figure 3. Meliola kamettiae sp. nov.

a - Appressorium; b - Phialide; c - Apical portion of the mycelial setae; d - Ascospores 
to uncinate, obtuse, bifid, trifid, often subdentate to furcated to branched at the tip, branches up to $30 \mu \mathrm{m}$ long. Perithecia scattered, up to $150 \mu \mathrm{m}$ in diam.; ascospores cylindrical, 4-septate, slightly constricted at the septa, 26$33 \times 8-11 \mu \mathrm{m}$.

Straight, slightly curved to uncinate, obtuse, bifid, trifid, often subdentate to furcated mycelial setae distinguishes this taxon from rest of the Meliola species reported on the members of the family Apocynaceae (Hansford 1961; Hosagoudar 1996, 2008; Hosagoudar et al. 1997).

\section{Meliola psophocarpi sp. nov.}

(Fig. 4)

\section{Material examined}

30.ix.2007, on leaves of Psophocarpus tetragonolobus L. (Fabaceae), 16 ${ }^{\text {th }}$ mile, Padinharathara, Wayanad, Kerala, India, coll. M.C. Riju, HCIO 48174 (holotype), TBGT 2910 (isotype), (MycoBank \# 518230).

Coloniae foliicolae, fructicolae, epiphyllae, tenues, dispersae, ad 3mm diam, saepe confluentes. Hyphae undulatae, plerumque opposite laxe ramosae, laxe vel arte reticulatae, cellulae $11-33 \times 4-7 \mu \mathrm{m}$. Appressoria alternata, unilateralis, ad 3\% opposita, recta vel leniter curvula, subantrorsa vel retrorsa, 11-20 $\mu$ m longa; cellulae basilares cylindraceae vel cuneatae, 2-11 $\mu \mathrm{m}$ longae; cellulae apicales ovatae, globosae, 8-11 $\mu \mathrm{m}$ diam. Phialides appressoriis intermixtae, oppositae, alternatae,

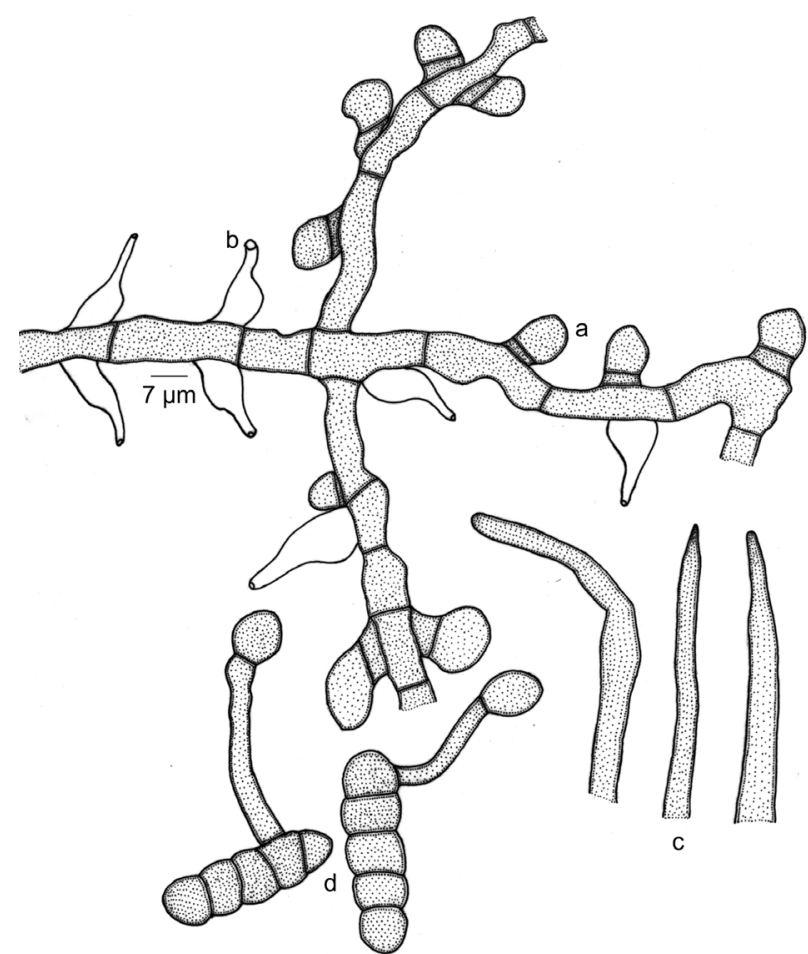

Figure 4. Meliola psophocarpi sp. nov.

a - Appressorium; b - Phialide; c - Apical portion of the mycelial setae; d - Ascospores unilateralis, ampulliformes, $13-20 \times 6-9 \mu \mathrm{m}$. Setae myceliales dispersae, simplices, rectae vel leniter curvulae, ad apicem acutae vel obtusae, ad $360 \mu \mathrm{m}$ longae. Perithecia dispersa, ad $130 \mu \mathrm{m}$ diam.; ascosporae cylindraceae, 4-septatae, leniter constrictus ad septatae, 33-38 x 8-11 $\mu \mathrm{m}$.

Colonies foliicolous, fructicolous, epiphyllous, thin, scattered, up to $3 \mu \mathrm{m}$ in diam., often confluent. Hyphae undulate branching mostly opposite at wide angles, loosely to closely reticulate, cells $11-33 \times 4-7 \mu \mathrm{m}$. Appressoria alternate, unilateral, up to $3 \%$ opposite, straight to slightly curved, subantrorse to retrorse, 11-20 $\mu \mathrm{m}$ long; stalk cells cylindrical to cuneate, 2-11 $\mu \mathrm{m}$ long; head cells ovate, globose, 8-11 $\mu \mathrm{m}$. Phialides mixed with appressoria, alternate, opposite, unilateral, ampulliform, 13-20 x 6-9 $\mu \mathrm{m}$. Mycelial setae scattered, simple, straight to slightly curved, acute to obtuse at the tip, up to $360 \mu \mathrm{m}$ long. Perithecia scattered, up to $130 \mu \mathrm{m}$ in diam.; ascospores cylindrical, 4 septate, slightly constricted at the septa, 33$38 \times 8-11 \mu \mathrm{m}$.

Psophocarpus tetragonolobus is a climbing shrub, native of South East Asia, has been extensively cultivated in the backyards for its quadrangular pods used in the culinary purposes. The leaves of this plant is being infected with the black mildew fungus and is similar to $M$. nyanzae in having the same digital formula but differs from it in not being a strong parasite in producing pathogenic symptoms (Hansford 1961; Hosagoudar 1996; Hu et al. 1996, 1999).

\section{REFERENCES}

Hansford, C.G. (1961). The Meliolaceae. AMonograph. Sydowia. Beih 2: 1-806.

Hosagoudar, V.B. (1996). Meliolales of India. Botanical Survey of India, Calcutta, 363pp.

Hosagoudar, V.B. (1996). Meliolales of India. Vol. II. Botanical Survey of India, Calcutta, 380pp.

Hosagoudar, V.B., T.K. Abraham \& P. Pushpangadan (1997). The Meliolineae - A Supplement. Tropical Botanic Garden and Research Institute, Palode, Thiruvananthapuram, Kerala, India, 201pp.

Hosagoudar, V.B., T.K. Abraham \& C.K. Biju (2001). Meliolaceae of Kerala, India - IX. Journal of Economic and Taxonomic Botany 25: 553-559.

Hu, Y., Y. Ouyang, S. Bin \& G. Jiang (1996). Flora Fungorum Sinicorum. Vol. 4. Meliolales (1). Science Press Beijing, 270pp + plate IV.

Hu, Y., S. Bin, Y. Ouyang \& G. Jiang (1999). Flora Fungorum Sinicorum. Vol. 11. Meliolales (2). Science Press Beijing, 252pp. 